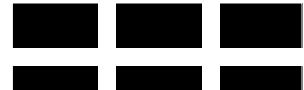 \\ THE WILLIAM DAVIDSON INSTITUTE AT THE UNIVERSITY OF MICHIGAN
}

\section{Bootstrap panel Granger-causality between government spending and revenue in the EU}

By: António Afonso and Christophe Rault

William Davidson Institute Working Paper Number 944

January 2009 


\title{
Bootstrap panel Granger-causality between government spending and revenue in the $\mathrm{EU}^{*}$
}

\author{
António Afonso ${ }^{\$}$ and Christophe Rault ${ }^{\#}$
}

\begin{abstract}
Using bootstrap panel analysis, allowing for cross-country correlation, without the need of pre-testing for unit roots, we study the causality between government revenue and spending for the EU in the period 1960-2006. Spend-and-tax causality is found for Italy, France, Spain, Greece, and Portugal, while tax-and-spend evidence is present for Germany, Belgium, Austria, Finland and the UK, and for several EU New Member States.
\end{abstract}

Keywords: panel causality, fiscal policy, EU.

JEL: C23, E62, H62.

\footnotetext{
* The opinions expressed are those of the authors and do not necessarily reflect those of the ECB or the Eurosystem.

\$ ECB, Directorate General Economics, Kaiserstraße 29, D-60311 Frankfurt am Main, Germany. ISEG/TULisbon - Technical University of Lisbon, Department of Economics; UECE - Research Unit on Complexity and Economics; R. Miguel Lupi 20, 1249-078 Lisbon, Portugal. UECE is supported by FCT (Fundação para a Ciência e a Tecnologia, Portugal), financed by ERDF and Portuguese funds. Emails: antonio.afonso@ecb.europa.eu, aafonso@iseg.utl.pt.

\# Université d’Orléans, LEO, CNRS, UMR 6221, Rue de Blois-B.P.6739, 45067 Orléans Cedex 2, France; CESifo and IZA, Germany; and William Davidson Institute at the University of Michigan, Ann Arbor, Michigan, USA; email: chrault@hotmail.com. web-site: http://membres.lycos.fr/chrault/ (corresponding author).
} 


\section{Non-Technical Summary}

Fiscal sustainability studies usually assess the existence of a long-term cointegration relationship between government revenue and spending. Nevertheless, an important feature linked to the existence of such cointegration relation is the direction of causality between spending and revenue, which conveys how fiscal policy is set-up in practice. Indeed, one may have one-way Granger-causality from spending (revenue) to revenue (spending), i.e. "tax-and-spend” (“spend-and-tax”) causality, two-way causality or no Granger-causality between revenue and spending.

The literature essentially assesses the existence of causality in a single country set-up. However, there is economic rational for undertaking a panel approach, taking advantage of non-stationary panel data econometric techniques. In the European Union (EU), and even if there is no single fiscal policy in place, panel analysis is relevant in the context of countries seeking to pursue sound fiscal policies within the framework of the Stability and Growth Pact. Cross-country dependence can be envisaged in the run-up to Economic and Monetary Union (EMU), via peer pressure or via integrated financial markets. Moreover, cross-country spillovers in government bond markets are to be expected, and interest rates comovements inside the EU have also gradually become more noticeable.

This paper contributes to the literature with a bootstrap panel analysis of causality between government revenue and spending in the EU country set, to assess which countries are characterised by a tax-and-spend or by a spend-and-tax behaviour during the period 1960-2006.

The results support the so-called spend-and-tax causality for such countries as Italy, France, Spain, Greece, and Portugal. Tax-and-spend evidence is present notably for 
Germany, Belgium, Austria Finland and the UK, and also for several EU New Member States. Some shifting regarding the direction of the causality patterns can also be detected, after the $2^{\text {nd }}$ half of the 1980 s, which may imply adjustments of fiscal behaviour in the run-up to EMU. 


\section{Introduction}

Fiscal sustainability studies usually assess the existence of a long-term cointegration relationship between government revenue and spending. ${ }^{1}$ Nevertheless, an important feature linked to the existence of such cointegration relation is the direction of causality between spending and revenue, which conveys how fiscal policy is set-up in practice. Indeed, one may have one-way Granger-causality from spending (revenue) to revenue (spending), i.e. "tax-and-spend” (“spend-and-tax") causality, two-way causality or no Granger-causality between revenue and spending.

The literature essentially assesses the existence of causality in a single country set-up. ${ }^{2}$ However, there is economic rational for undertaking a panel approach, taking advantage of non-stationary panel data econometric techniques. In the European Union (EU), and even if there is no single fiscal policy in place, panel analysis is relevant in the context of countries seeking to pursue sound fiscal policies within the framework of the Stability and Growth Pact. Cross-country dependence can be envisaged in the run-up to Economic and Monetary Union (EMU), via peer pressure or via integrated financial markets. Moreover, cross-country spillovers in government bond markets are to be expected, and interest rates comovements inside the EU have also gradually become more noticeable.

This paper contributes to the literature with a bootstrap panel analysis of causality between government revenue and spending in the EU country set, to assess which countries are characterised by a tax-and-spend or by a spend-and-tax behaviour during the period 1960-2006. Section two explains the methodology, section three reports the empirical analysis and section four concludes.

\footnotetext{
${ }^{1}$ Afonso (2005) explains the relevant linkages and reviews the empirical evidence. Afonso and Rault (2007) test the cointegration relationship with panel unit root and cointegration tests, allowing for correlation within and between units.

${ }^{2}$ See, for instance, von Fursternberg et al. (1986), Chang et al. (2002), Payne (2004), and Kollias and Paleologou (2006).
} 


\section{Series specific panel Granger causality test methodology}

We use the panel data approach developed by Kónya (2006), based on a bivariate finite-order vector autoregressive model, and we apply it in our context to general government revenue, $R$, and spending, $G:^{3}$

$$
\left\{\begin{array}{l}
R_{i t}=\alpha_{1, i}+\sum_{j=1}^{p_{1 i}} \beta_{1, i, j} R_{i, t-j}+\sum_{j=1}^{p_{2 i}} \gamma_{1, i, j} G_{i, t-j}+\varepsilon_{1, i, t} t=1, \ldots, T i=1, \ldots, N \\
G_{i t}=\alpha_{2, i}+\sum_{j=1}^{p_{1 i}} \beta_{2, i, j} R_{i, t-j}+\sum_{j=1}^{p_{2 i}} \gamma_{2, i, j} G_{i, t-j}+\varepsilon_{2, j, t} t=1, \ldots, T i=1, \ldots, N
\end{array}\right.
$$

where the index $i(i=1, \ldots, N)$ denotes the country, the index $t(t=1, \ldots, T)$ the period, $j$ the lag, and $p_{1 i}, p_{2 i}$ and $p_{3 i}$, indicate the longest lags in the system. The error terms, $\varepsilon_{1, i, t}$ and $\varepsilon_{2, i, t}$, are supposed to be white-noises (i.e. they have zero means, constant variances and are individually serially uncorrelated) and may be correlated with each other for a given country, but not across countries.

System (1) is estimated by the Seemingly Unrelated Regressions (SUR) procedure, since possible links may exist among individual regressions via contemporaneous correlation ${ }^{4}$ within the two equations. Wald tests for Granger causality are performed with country specific bootstrap critical values generated by simulations.

With respect to system (1), in country $i$ there is one-way Granger-causality from $G$ to $R$ if in the first equation not all $\gamma_{1, i}$ are zero but in the second all $\beta_{2, i}$ are zero; there is one-way Granger-causality from $R$ to $G$ if in the first equation all $\gamma_{1, i}$ are zero

\footnotetext{
${ }^{3}$ We are grateful to L. Kónya for providing his TSP codes, which we have adapted for our analysis.

${ }^{4}$ This assumption is very likely to be relevant for many macroeconomic time series for EU countries for which strong economic links exist.
} 
but in the second not all $\beta_{2, i}$ are zero; there is two-way Granger-causality between $R$ to $G$ if neither all $\beta_{2, i}$ nor all $\gamma_{1, i}$ are zero; and there is no Granger-causality between $R$ to $G$ if all $\beta_{2, i}$ and $\gamma_{1, i}$ are zero. $^{5}$

This procedure has several advantages. Firstly, it does not assume that the panel is homogeneous, being possible to test for Granger-causality on each individual panel member separately. However, since contemporaneous correlation is allowed across countries, it makes possible to exploit the extra information provided by the panel data setting. Secondly, it does not require pre-testing for unit roots and cointegration (since country specific bootstrap critical values are generated), though it still requires the specification of the lag structure. This is an important feature since the unit-root and cointegration tests in general suffer from low power, and different tests often lead to contradictory outcomes. Thirdly, this approach allows detecting for how many and for which members of the panel there exists one-way, two-way, or no Granger-causality.

\section{Econometric investigation}

Data for general government expenditure and revenue are taken from the European Commission AMECO database. ${ }^{6}$ The data cover the periods 1960-2006 for the EU15 countries, and 1998-2006 for the EU25 countries and the unbalanced panels are used for the SUR analysis and Granger-causality testing. ${ }^{7}$

\footnotetext{
${ }^{5}$ As stressed by Kónya (2006) this definition implies causality for one period ahead.

6 The AMECO codes are as follows: total expenditure (\% of GDP), 1.0.319.0.UUTGE, .1.0.319.0.UUTGF; total revenue (\% of GDP), .1.0.319.0.URTG, .1.0.319.0.URTGF.

${ }^{7}$ EU15: Austria, Belgium, Denmark, Finland, France, Germany, Greece, Italy, Ireland, Luxembourg, the Netherlands, Portugal, Spain, United Kingdom, and Sweden. EU25: EU15, Bulgaria, Czech Republic, Estonia, Hungary, Lithuania, Latvia, Malta, Poland, Slovakia and Slovenia.

${ }^{8}$ For the SUR approach to work properly, the time series dimension should be substantially larger than $N$, a condition that is only fulfilled for the EU25 over the 1998-2006 period. Therefore, for the EU25 panels the SUR estimation is performed on the (unbalanced) 1970-2006 period.
} 
We use government spending and revenue data as a ratio of GDP. Apart form the fact that ratios of nominal magnitudes are commonly used in the international debate, it is also important to scale the variables for the panel approach. In addition, the bootstrap causality test that we use does not require unit root testing.

Table 1 shows the results of the causality tests for the EU15 panel for the period 1960-2006. It is possible to observe that while government revenue positively causes government spending for Germany and negatively for Ireland, there are more cases pointing to the spend-and-tax hypothesis: Austria, France, Greece, Italy, Spain, and Sweden.

Table 1a - Causality from government revenue to spending, EU15 (1960-2006)

\begin{tabular}{lccccc}
\hline \hline & Estimated & Test Statistic & \multicolumn{3}{c}{ Bootstrap critical values } \\
\cline { 4 - 6 } coefficient & & $1 \%$ & $5 \%$ & $10 \%$ \\
\hline Austria & 0.1351 & 1.2361 & 26.5043 & 15.5115 & 11.5606 \\
Belgium & 0.0183 & 0.0600 & 21.6994 & 12.7869 & 8.60072 \\
Denmark & -0.0238 & 0.1362 & 24.1007 & 13.7943 & 9.80305 \\
Finland & 0.1050 & 1.6209 & 21.8583 & 13.4235 & 10.4536 \\
France & -0.0119 & 0.0153 & 33.3617 & 23.3719 & 16.5679 \\
Germany & 0.4409 & $28.130 * * *$ & 23.0660 & 14.5004 & 9.82668 \\
Greece & -0.0986 & 1.5955 & 27.2009 & 16.9224 & 12.2377 \\
Ireland & -0.2049 & $11.572 *$ & 22.1834 & 12.5130 & 9.63277 \\
Italy & 0.0003 & 0.0004 & 21.0231 & 16.4763 & 12.2038 \\
Luxembourg & 0.2337 & 6.8957 & 21.7075 & 12.2952 & 9.19950 \\
Netherlands & 0.1453 & 1.9476 & 21.0882 & 13.4699 & 9.83869 \\
Portugal & 0.1810 & 7.7905 & 29.4152 & 20.8129 & 16.4777 \\
Spain & -0.0867 & 2.4448 & 32.6605 & 23.7844 & 17.7405 \\
Sweden & 0.0281 & 0.1175 & 25.0536 & 15.5121 & 10.4427 \\
UK & 0.1628 & 3.6575 & 17.4399 & 9.79579 & 7.52149 \\
\hline \hline ***, **, *: significance at the $1 \%, 5 \%$ and $10 \%$ levels, respectively. &
\end{tabular}

$\mathrm{H}_{0}: R$ does not cause $G$.

Table 1b - Causality from government spending to revenue, EU15 (1960-2006)

\begin{tabular}{lllccc}
\hline \hline & \multirow{2}{*}{$\begin{array}{c}\text { Estimated } \\
\text { coefficient }\end{array}$} & Test Statistic & \multicolumn{3}{c}{ Bootstrap critical values } \\
\cline { 4 - 6 } & & $1 \%$ & $5 \%$ & $10 \%$ \\
\hline Austria & 0.2290 & $8.2731^{*}$ & 22.2499 & 11.1867 & 7.9895 \\
Belgium & 0.0052 & 0.0266 & 18.3643 & 10.5409 & 7.73236 \\
Denmark & 0.1307 & 3.9247 & 23.6322 & 12.5703 & 9.37391 \\
Finland & 0.0632 & 1.1145 & 18.9469 & 13.1284 & 9.68753 \\
France & 0.3230 & $25.450^{* * *}$ & 19.3738 & 14.0002 & 10.7197 \\
Germany & 0.1468 & 5.0713 & 18.5037 & 11.7241 & 8.79791 \\
Greece & 0.1043 & $12.325^{*}$ & 28.6306 & 16.7483 & 11.6541 \\
Ireland & 0.0988 & 6.3321 & 29.5567 & 12.8465 & 8.51660 \\
Italy & 0.1363 & $17.783^{* *}$ & 27.4934 & 16.1808 & 11.8194 \\
Luxembourg & 0.0806 & 0.7435 & 20.2061 & 11.3574 & 8.39400
\end{tabular}




\begin{tabular}{llllll} 
Netherlands & 0.0871 & 0.9737 & 19.4031 & 11.6964 & 8.71781 \\
Portugal & 0.1075 & 4.9057 & 26.1445 & 15.9634 & 13.1014 \\
Spain & 0.1340 & $10.590 *$ & 17.4415 & 11.5850 & 8.50721 \\
Sweden & 0.1285 & $8.1168 *$ & 15.9548 & 10.9160 & 7.76927 \\
UK & -0.0434 & 0.3727 & 20.3780 & 10.9510 & 6.97039 \\
\hline \hline & $* * *, * *, *:$ significance at the 1\%, 5\% and 10\% levels, respectively. \\
$\mathrm{H}_{0}: G$ does not cause $R$.
\end{tabular}

We also compared the results (not shown) for two sub-periods, 1960-1985 and 1986-2006. In the first sub-period, causality from revenue to spending occurs in six countries, while causality from spending to revenue is detected for Greece, Italy and Portugal. In addition, the tax-and-spend result is obtained for Portugal in the second sub-period while a negative causality from revenue to spending is found for Italy and Belgium, which may signal increased concerns regarding fiscal behaviour in the runup to EMU. On the other hand, the spend-and-tax result occurs in the second subperiod for France and Ireland.

Table 2 reports the results for the EU25 country sample, considering most of the EU New Member States (NMS). The spend-and-tax result is still found for Austria, France, Greece, Italy, and Spain, and causality still runs from revenue to spending in the case of Germany and Luxembourg. On the other hand, the evidence shows causality from revenue to spending in several EU New Members States: Czech Republic, Estonia, Lithuania, and Poland. Finally, two countries exhibit two-way, bidirectional causality between government revenue and spending: Ireland and Slovakia. Table 3 summarises the causality results.

Table 2a - Causality from government revenue to spending, EU25 (1960-2006, 19982006 for NMS)

\begin{tabular}{lclccc}
\hline \hline & \multirow{2}{*}{$\begin{array}{c}\text { Estimated } \\
\text { coefficient }\end{array}$} & Test Statistic & \multicolumn{3}{c}{ Bootstrap critical values } \\
\cline { 4 - 6 } & & 3.6305 & 41.2461 & 23.1395 & 16.6998 \\
\hline Austria & 0.2009 & 0.0020 & 32.2159 & 17.9067 & 13.2455 \\
Belgium & -0.0010 & 1.9209 & 72.7410 & 18.1467 & 10.6635 \\
Bulgaria & 2.1296 & $117.58^{* * *}$ & 60.7540 & 22.8137 & 16.6407 \\
Czech Republic & 1.1902 & 1.3795 & 41.9757 & 22.3520 & 16.6643 \\
Denmark & -0.0645 & & &
\end{tabular}




\begin{tabular}{lrllll} 
Estonia & 0.5861 & $116.77^{* * *}$ & 72.8279 & 24.2003 & 16.6886 \\
Finland & 0.1707 & 6.4720 & 46.0596 & 26.9281 & 20.8231 \\
France & 0.0676 & 0.7831 & 43.3779 & 24.2287 & 19.8115 \\
Germany & 0.4764 & $47.753^{* * *}$ & 34.4426 & 23.1298 & 15.8835 \\
Greece & -0.1240 & 3.3001 & 29.8829 & 19.4335 & 14.3818 \\
Hungary & 1.3929 & 13.215 & 133.850 & 33.8927 & 22.9206 \\
Ireland & -0.1863 & $10.846^{*}$ & 32.9529 & 16.8088 & 9.91600 \\
Italy & -0.0093 & 0.0406 & 40.0782 & 24.0417 & 18.1905 \\
Lithuania & 0.7834 & $71.052^{* * *}$ & 45.0261 & 25.1628 & 17.2383 \\
Luxembourg & 0.2527 & $11.364^{*}$ & 36.1252 & 17.8449 & 10.5813 \\
Latvia & -0.2954 & 0.8001 & 72.6016 & 26.0319 & 18.1718 \\
Malta & 0.1944 & 0.0612 & 66.7247 & 27.0500 & 18.7337 \\
Netherlands & 0.0917 & 1.1335 & 40.9455 & 20.3194 & 14.3195 \\
Poland & 0.7741 & $16.350^{*}$ & 75.7026 & 29.3214 & 16.1523 \\
Portugal & 0.1771 & 9.9942 & 66.3728 & 34.3644 & 24.1508 \\
Spain & -0.0987 & 3.6759 & 50.0771 & 32.0511 & 26.2648 \\
Slovakia & 0.8231 & $91.575^{* * *}$ & 47.1513 & 18.5281 & 12.4573 \\
Slovenia & 1.3726 & 0.9320 & 66.6083 & 25.8891 & 17.3368 \\
Sweden & 0.0286 & 0.1586 & 34.9508 & 18.8386 & 13.6560 \\
UK & 0.2061 & 6.7309 & 27.4755 & 14.3481 & 10.2508 \\
\hline \hline
\end{tabular}

$* * *, * *, *$ : significance at the $1 \%, 5 \%$ and $10 \%$ levels, respectively.

$\mathrm{H}_{0}: R$ does not cause $G$.

Table 2b - Causality from government spending to revenue, EU25 (1960-2006, 19982006, for NMS)

\begin{tabular}{lclccc}
\hline \hline & Estimated & Test Statistic & \multicolumn{3}{c}{ Bootstrap critical values } \\
\cline { 4 - 5 } & coefficient & & $1 \%$ & $5 \%$ & $10 \%$ \\
\hline Austria & 0.2529 & $12.044^{*}$ & 19.5303 & 13.4184 & 10.2562 \\
Belgium & 0.0224 & 0.54781 & 19.5653 & 13.9294 & 10.8562 \\
Bulgaria & 1.6730 & 1.04981 & 42.6198 & 25.0232 & 10.3543 \\
Czech Republic & -0.0349 & 0.41078 & 71.0631 & 41.1924 & 28.0181 \\
Denmark & 0.1089 & 3.27944 & 26.2961 & 19.5282 & 14.9182 \\
Estonia & -0.0841 & 2.03649 & 72.0515 & 39.0268 & 28.0185 \\
Finland & 0.0329 & 0.42829 & 21.5672 & 13.2089 & 10.1670 \\
France & 0.2434 & $18.0268 * *$ & 21.3095 & 13.3523 & 10.4775 \\
Germany & 0.0991 & 3.13249 & 20.9963 & 14.3719 & 10.3984 \\
Greece & 0.1141 & $19.9956 *$ & 28.9023 & 21.6341 & 17.0258 \\
Hungary & -0.3327 & 0.57414 & 51.9562 & 29.3867 & 18.4169 \\
Ireland & 0.1169 & $9.55691^{*}$ & 19.7658 & 12.5920 & 9.21358 \\
Italy & 0.1159 & $16.4259 * *$ & 22.1347 & 15.3167 & 11.6779 \\
Lithuania & -0.0018 & 0.00152 & 69.7456 & 45.8297 & 29.9929 \\
Luxembourg & 0.0927 & 1.18539 & 21.8078 & 13.8562 & 10.6759 \\
Latvia & 0.3720 & 0.78022 & 32.1787 & 21.9743 & 16.1741 \\
Malta & 0.1615 & 0.09375 & 28.1466 & 17.6842 & 10.9345 \\
Netherlands & 0.0557 & 0.48933 & 20.5256 & 14.6298 & 12.2631 \\
Poland & -0.4814 & 6.97142 & 75.3512 & 40.3326 & 28.0697 \\
Portugal & 0.1048 & 7.61307 & 30.8244 & 20.4392 & 15.4292 \\
Spain & 0.1273 & $12.011 *^{*}$ & 25.0689 & 17.7928 & 11.3755 \\
Slovakia & 0.1732 & $40.8910 * *$ & 67.3608 & 36.4847 & 29.9371 \\
Slovenia & 0.0828 & 0.00149 & 41.5854 & 23.4056 & 14.1824 \\
Sweden & 0.1010 & 6.42458 & 18.9381 & 12.8071 & 9.37407 \\
UK & -0.0523 & 0.63520 & 18.1513 & 11.5070 & 8.34389 \\
\hline \hline
\end{tabular}

$* * *, * *, *$ : significance at the $1 \%, 5 \%$ and $10 \%$ levels, respectively.

$\mathrm{H}_{0}$ : $G$ does not cause $R$. 
Table 3 - Summary of results

\begin{tabular}{cccc}
\hline \multirow{2}{*}{ Panel } & \multicolumn{2}{c}{ Revenue $\Rightarrow$ Spending } & $\begin{array}{c}\text { Spending } \Rightarrow \text { Revenue } \\
\text { (spend-and-tax) }\end{array}$ \\
\cline { 2 - 4 } & $\begin{array}{c}\Delta R \Rightarrow \Delta G \\
\text { (tax-and-spend) }\end{array}$ & $\Delta R \Rightarrow \nabla G$ & Austria, Italy, France, \\
EU15, 1960-2006 & Germany & Ireland & Greece, Italy, Portugal \\
\hline EU15, 1960-1985 & $\begin{array}{c}\text { Belgium, Germany, } \\
\text { Spain, Sweden, } \\
\text { Luxembourg, UK }\end{array}$ & & France, Ireland \\
\hline EU15, 1986-2006 & $\begin{array}{c}\text { Austria, Finland, } \\
\text { Portugal }\end{array}$ & $\begin{array}{c}\text { Belgium, Denmark, } \\
\text { Italy, Sweden }\end{array}$ & Ireland \\
\hline EU25, 1960-2006; \\
NMS, 1998-2006 & $\begin{array}{c}\text { Czech Republic, } \\
\text { Estonia, Lithuania, } \\
\text { Poland, Slovakia } \\
\text { Germany, } \\
\text { Luxembourg }\end{array}$ & $\begin{array}{c}\text { Slovakia, Austria, France, } \\
\text { Greece, Ireland, Italy, Spain }\end{array}$ \\
& & & \\
\hline
\end{tabular}

\section{Conclusion}

We used a bootstrap panel analysis of causality between government revenue and spending for the EU, which allows for contemporaneous correlation across countries and dispenses the need of pre-testing for unit roots. The results support the so-called spend-and-tax causality for such countries as Italy, France, Spain, Greece, and Portugal. Tax-and-spend evidence is present notably for Germany, Belgium, Austria Finland and the UK, and also for several EU New Member States. Some shifting regarding the direction of the causality patterns can also be detected, after the $2^{\text {nd }}$ half of the 1980s, which may imply adjustments of fiscal behaviour in the run-up to EMU. 


\section{References}

Afonso, A. (2005). "Fiscal Sustainability: the Unpleasant European Case", FinanzArchiv, 61(1), 19-44.

Afonso, A. and Rault, C. (2007). "What do we really know about fiscal sustainability in the EU? A panel data diagnostic”, ECB Working Paper n. 820.

Chang, T.; Liu, W., Caudill, S. (2002). “Tax-and-Spend, Spend-and-Tax, or Fiscal Synchronization: New Evidence for Ten Countries,” Applied Economics, 34(12), $1553-1561$.

Kollias, C., Paleologou, S.-M. (2006). "Fiscal policy in the European Union: Tax and spend, spend and tax, fiscal synchronisation or institutional separation?” Journal of Economic Studies, 33(2), 108-120.

Kónya, L. (2006). "Exports and growth: Granger Causality analysis on OECD countries with a panel approach”, Economic Modelling, 23(6), 978-992.

Payne, J. (2004). “The tax-spend debate: Time series evidence from state budgets”, Public Choice, 95(3-4), 307-320.

von Furstenberg, G.; Green, R., Jeong, J. (1986). “Tax and spend, or spend and tax?” Review of Economics and Statistics, (68)2, 179-188. 


\section{DAVIDSON INSTITUTE WORKING PAPER SERIES - Most Recent Papers}

The entire Working Paper Series may be downloaded free of charge at: www.wdi.umich.edu

CURRENT AS OF 1/30/09

\begin{tabular}{|c|c|c|}
\hline Publication & Authors & Date \\
\hline $\begin{array}{l}\text { No. 944: Bootstrap panel Granger-causality between government } \\
\text { spending and revenue in the EU }\end{array}$ & $\begin{array}{l}\text { Antonio Afonso and Christophe } \\
\text { Rault }\end{array}$ & Jan 2009 \\
\hline No. 943: Regional Determinants of FDI Distribution in Poland & $\begin{array}{l}\text { Agnieszka Chidlow and Stephen } \\
\text { Young }\end{array}$ & Nov 2008 \\
\hline No. 942: Structural Reform and Firm Exports & $\begin{array}{l}\text { Alvaro Cuervo-Cazurra \& Luis } \\
\text { Alfonso Dau }\end{array}$ & Sept 2008 \\
\hline $\begin{array}{l}\text { No. 941: Exploring The Relationship Between Military Spending \& } \\
\text { Human Rights Performance In South Asia }\end{array}$ & $\begin{array}{l}\text { Krishna Chaitanya, Vadlamannati } \\
\text { and K K Shakya Lahiru Pathmalal }\end{array}$ & Oct 2008 \\
\hline $\begin{array}{l}\text { No. 940: Structural Reform And Firm Profitability In Developing } \\
\text { Countries }\end{array}$ & $\begin{array}{l}\text { Alvaro Cuervo-Cazurra \& Luis } \\
\text { Alfonso Dau }\end{array}$ & July 2008 \\
\hline $\begin{array}{l}\text { No. 939: Does Timing Of Elections Instigate Riots? } \\
\text { A Subnational Study Of } 16 \text { Indian States, } 1958 \text { - } 2004\end{array}$ & Krishna Chaitanya Vadlamannati & Oct 2008 \\
\hline $\begin{array}{l}\text { No. 938: Price Setting And Market Structure: An Empirical Analysis Of } \\
\text { Micro Data }\end{array}$ & Fabrizio Coricelli \& Roman Horvath & Sept 2008 \\
\hline $\begin{array}{l}\text { No. 937: Inflation Differentials in EU New Member States: An Empirical } \\
\text { Evidence }\end{array}$ & Roman Horvath \& Kamila Koprnicka & Oct 2008 \\
\hline $\begin{array}{l}\text { No. 936: Market Reforms and Growth in Post-socialist Economies: } \\
\text { Evidence from Panel Cointegration and Equilibrium Correction Model }\end{array}$ & Igor Pelipas and Alexander Chubrik & Sept 2008 \\
\hline $\begin{array}{l}\text { No. 935: Derivatives trading and the volume-volatility link in the Indian } \\
\text { Stock Market }\end{array}$ & $\begin{array}{l}\text { S. Bhaumiky, M. Karanasosy and } \\
\text { A. Kartsaklas }\end{array}$ & April 2008 \\
\hline $\begin{array}{l}\text { No. 934: Yuan Real Exchange Rate Undervaluation, 1997-2006. How } \\
\text { Much, How Often? Not Much, Not Often }\end{array}$ & $\begin{array}{l}\text { Jeff Chen, Wende Deng \& David } \\
\text { Kemme }\end{array}$ & Aug 2008 \\
\hline $\begin{array}{l}\text { No. 933: How Important Are Foreign Shocks in Small Open Economy? } \\
\text { The Case of Slovakia }\end{array}$ & $\begin{array}{l}\text { Roman Horváth and Marek } \\
\text { Rusnák }\end{array}$ & Sept 2008 \\
\hline $\begin{array}{l}\text { No. 932: Estimating Poverty for Indigenous Groups in Chile } \\
\text { by Matching Census and Survey Data }\end{array}$ & $\begin{array}{l}\text { Claudio A. Agostini, Philip H. } \\
\text { Brown, and Andrei Roman }\end{array}$ & Aug 2008 \\
\hline $\begin{array}{l}\text { No. 931: Is There Electoral Cycles In Globalization Process? Evidence } \\
\text { From } 78 \text { Democratic Countries, } 1975 \text { - } 2006\end{array}$ & Krishna Chaitanya Vadlamannati & Sept 2008 \\
\hline No. 930: Lobbying, Corruption \& Other Banes & $\begin{array}{l}\text { Nauro Campos \& Francesco } \\
\text { Giovannoni }\end{array}$ & Sept 2008 \\
\hline $\begin{array}{l}\text { No. 929: Do Elections Slow Down Economic Globalization Process In } \\
\text { India? It's Politics Stupid! }\end{array}$ & Krishna C Vadlamannati & Aug 2008 \\
\hline $\begin{array}{l}\text { No. 928: Impact Of Institutional Quality On Human Rights Abuses } \\
\text { In Transition Economies }\end{array}$ & $\begin{array}{l}\text { Krishna C Vadlamannati \& Artur } \\
\text { Tamazian }\end{array}$ & July 2008 \\
\hline $\begin{array}{l}\text { No. 927: Do Choice \& Speed Of Reforms Matter For } \\
\text { Human Rights During Transition? }\end{array}$ & Krishna Chaitanya Vadlamannati & July 2008 \\
\hline $\begin{array}{l}\text { No. 926: Socioeconomic, Institutional \& Political Determinants Of } \\
\text { Human Rights Abuses: A Subnational Study Of India, } 1993-2002\end{array}$ & Krishna Chaitanya Vadlamannati & July 2008 \\
\hline $\begin{array}{l}\text { No. 925: Does the Entry Mode of Foreign Banks Matter for Bank } \\
\text { Efficiency? Evidence from the Czech Republic, Hungary, and } \\
\text { Poland }\end{array}$ & $\begin{array}{l}\text { Ngoc-Anh Vo Thi \& Dev } \\
\text { Vencappa }\end{array}$ & July 2008 \\
\hline No. 924: Impact Of Economic Reforms On Poverty - Indian Experience & Krishna Chaitanya Vadlamannati & July 2008 \\
\hline $\begin{array}{l}\text { No. 923: India \& South Asia - Indian Economic Reforms \& Direct } \\
\text { Foreign Investments: How Much Difference Do They Make To } \\
\text { Neighbors? }\end{array}$ & Krishna Chaitanya Vadlamannati & July 2008 \\
\hline $\begin{array}{l}\text { No. 922: The Effects of Monetary Policy in the Czech Republic: } \\
\text { An Empirical Study }\end{array}$ & $\begin{array}{l}\text { Magdalena Morgese Borys and } \\
\text { Roman Horváth }\end{array}$ & May 2008 \\
\hline $\begin{array}{l}\text { No. 921: Goods Market Integration in Russia during the Economic } \\
\text { Upturn }\end{array}$ & Konstantin Gluschenko & May 2008 \\
\hline
\end{tabular}

